Original Article

\title{
Notes on the biological development of the darkling beetle Blaps nefrauensis nefrauensis Seidlitz, 1893 (Coleoptera: Tenebrionidae)
}

\author{
Notas sobre o desenvolvimento biológico do besouro escuro Blaps nefrauensis \\ nefrauensis Seidlitz, 1893 (Coleoptera: Tenebrionidae)
}

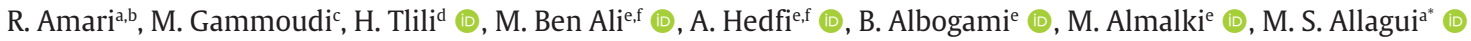 \\ and M. S. Achouri ${ }^{\mathrm{b}}$ \\ a University of Gafsa, Faculty of Sciences of Gafsa, Research Unit of Macromolecular Biochemistry and Genetic, Gafsa, Tunisia \\ ${ }^{\mathrm{b}}$ University of Tunis El Manar, Faculty of Sciences of Tunis, Laboratory of Bio-ecology and Evolutionary Systematics, Tunis, Tunisia \\ ' University of Tunis El Manar, Faculty of Science of Tunis, Animal Reproduction and Developmental Biology, Tunis, Tunisia \\ dUniversity of Sorbonne, Institute of Systematic, Evolution and Biodiversity - ISYEB, National Museum of Natural History, National Center for \\ Scientific Research, Paris, French \\ e Department of Biology, College of Sciences, Taif University, P.O. Box 11099, Taif 21944, Saudi Arabia \\ ${ }_{\mathrm{f}}$ University of Carthage, Faculty of Sciences of Bizerte, Laboratory of Environment Biomonitoring, LR01 ES14, Zarzouna 7021, Tunisia
}

\begin{abstract}
Several endemic species of Blaps occur in Tunisia, and the species Blaps nefrauensis nefrauensis has been reported in Moulares (urban zone in west-central Tunisia), where it lives and reproduces in home gardens and old buildings. The aim of this work is to study the life cycle of the darkling beetle, considering both field and laboratory rearing conditions. As a result, the beetle species has different developmental stages (egg, larva, prepupa, pupa, and adult) that last about 15 months. Each year during the same period, adults emerge (early summer) and expire (late autumn), larvae hatch (late summer) and pupate (early summer). There is only one generation per year. Females began laying eggs in late July. The eggs were ovoid, white, and about $2.7 \mathrm{~mm}$ in length and $1.5 \mathrm{~mm}$ in width. Embryogenesis took an average of nine days. The first instar larvae were at initially only $4.5 \mathrm{~mm}$ long and ivory white in color. A brief description of the newly egg hatched larva was provided; thus, the nerve fibers innervating the apical setae in the antennae and ligula were detected. Further light microscopic examination of the embryo before hatching from the egg pointed out that the antennal sensilla are protected during the embryogenesis stage.

Keywords: Blaps nefrauensis nefrauensis, life cycle stages, first instar larvae, larval antennae, larval ligula.

Resumo

Várias espécies endêmicas de Blaps ocorrem na Tunísia, e a espécie Blaps nefrauensis nefrauensis foi relatada em Moulares (zona urbana no centro-oeste da Tunísia), onde vive e se reproduz em jardins domésticos e prédios antigos. O objetivo deste trabalho é estudar o ciclo de vida do besouro escuro, considerando as condições de criação em campo e em laboratório. Como resultado, a espécie de besouro tem diferentes estágios de desenvolvimento (ovo, larva, prepupa, pupa e adulto) que duram cerca de 15 meses. Todos os anos, durante o mesmo período, os adultos emergem (início do verão) e expiram (final do outono), as larvas eclodem (final do verão) e se tornam pupas (início do verão). Existe apenas uma geração por ano. As fêmeas começaram a botar ovos no final de julho. Os ovos eram ovóides, brancos, com cerca de 2,7 mm de comprimento e 1,5 mm de largura. A embriogênese demorou em média nove dias. As larvas de primeiro instar tinham inicialmente apenas $4,5 \mathrm{~mm}$ de comprimento e uma cor branca marfim. Foi fornecida uma breve descrição da larva recém-eclodida; assim, as fibras nervosas que inervam as cerdas apicais nas antenas e ligulas foram detectadas. Um exame microscópico de luz posterior do embrião antes da eclosão do ovo mostrou que as sensilas antenais são protegidas durante o estágio de embriogênese.
\end{abstract}

Palavras-chave: Blaps nefrauensis nefrauensis, estágios do ciclo de vida, larvas de primeiro instar, antenas larvais, lígula larval.

\section{Introduction}

Tenebrionidae is a highly diverse family of Coleoptera is divided into ten subfamilies, 96 tribes, 61 subtribes, 2300 genera, and about 20000 species distributed worldwide (Löbl et al., 2008; Matthews et al., 2010; Ślipiński et al., 2011).
The subfamily Tenebrioninae Latreille, 1802 consists of 29 tribes in which the tribe Blaptini Leach, 1815 includes five subtribes (Blaptina Leach, 1815, Gnaptorina Medvedev, 2001, Gnaptorinina Medvedev, 2001, Prosodina Skopin,

*e-mail: amsallagui@yahoo.fr

Received: December 6, 2020 - Accepted: February 16, 2021 
1960, Remipedellina Semenov, 1907). The largest in the subtribe Blaptina is the genus Blaps Fabricus, 1775 (type genus) which encompasses more than 250 species. It is an emblematic group of large flightless beetles adapted to arid and semi-arid terrestrial ecosystems. With about 230 species, the subgenus Blaps is the most diverse of the four extant subgenera (Arenoblaps Medvedev, Blaps Fabricus, Dineria Motscnhulsky and Prosoblapsia Skopin and Kaszab) (Löbl et al., 2008). Within the subgenus Blaps about 140 species are Eurasian, whereas about 90 species mostly occur in the Mediterranean pool (Soldati et al., 2017). In Tunisia (North Africa), 17 taxa (species and subspecies belonging to the subgenus Blaps) at least were listed (B. appendiculata Motschulsky, 1851, B. approximans Seidlitz, 1893 ; B. binominata Escalera, 1914, B. divergens Fairmaire, 1875, B. emondi Solier,1848, B. bifurcata strauchii Reiche, 1861b: 88 , B. gigas Linnaeus, 1767, B. nefrauensis nefrauensis Seidlitz, 1893 , B. nitens nitens Laporte, 1840, B. nitens praedeserta Koch, 1944 , B. nitens requieni Solier, 1848, B.nitiduloides L. Soldati, 2017, B. plana Solier, 1848, B. propheta propheta Reiche, 1861, B. pubescens Allard, 1880, B. superstitiosa superstitiosa Erichson, 1841) (Bouchard et al., 2005; Löbl et al., 2008; Condamine et al., 2011, 2013; Soldati et al., 2017).

Among the coleopteran species reported in Tunisia, Blaps nefrauensis nefrauensis Seidlitz, 1893, occurred in Gafsa (Soldati et al., 2017). This desert darkling beetle was widespread in summer in Moulares (Gafsa), invading local gardens and ruins, where it mates, feeds and lays its eggs. This makes it useful as a model organism to study the life cycle of the Blaps species. Knowing that the life histories of the tenebrionid species of North Africa have received little attention to date. (Halstead, 1967; Menon and Putnam, 1988; De Los Santos et al., 1988, 2006; Zanuncio et al., 2001). Therefore, the studies conducted in this zoogeography focused mainly on the biogeography and taxonomy of beetles. On the other hand, first instar larvae in Blaps species were small and white transparent, so that more details could be seen and investigated under the light microscope.

The present work was a contribution to know more about the life cycle of $B$. nefrauensis and to provide notes on the first instar larvae, especially on the innervations of the ligular and antennal setae. This may be evaluated for use with other species of the Blaps genus or Blabtini tribe.

\section{Material and Methods}

\subsection{Identification}

The identification of the specimens was based on diagnostic keys and characteristics from the literature (original descriptions): (Seidlitz, 1893; Normand, 1937), and in comparison with the Blaps species illustrated in the following work by Laurent Soldati and Fabian Condamine (Western Palearctic tenebrionid specialists): (Soldati et al., 2009, 2017; Condamine et al., 2011, 2013).

\subsection{Field and laboratory investigation}

The different life cycle stages of $B$. nefrauensis were followed in a domestic garden in Moulares center

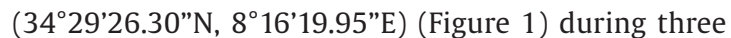
years (from June 2017 to June 2020), where the beetles mate, oviposit and feed while exploring its environment (decomposing plant matter, dead insect, human food waste, wet soil, stones, boards, concealed shelters...), they were simultaneously observed in the rearing laboratory. Field searches for adult Blaps and sampling were conducted fortnightly at night from early May to late December each year for three years. Beetles were counted at each sampling and most were returned to the field after having measured their size $(\delta$ and $q$ ). About Five pairs of beetles were taken for breading at each sampling. Field searches for eggs, larvae, prepupae and pupae were carried out every week throughout the year. Mating was monitored both in the field and during laboratory rearing. Larval molting was monitored weekly in laboratory (daily for the first weeks of larval age). Considering that it was difficult to detect egg hatch in the field, some copulating pairs of beetles were placed in buckets ( $40 \mathrm{~cm}$ diameter $50 \mathrm{~cm}$ depth) in the breeding laboratory (at room temperature away from wind, rain, and other climatic factors). About onequarter of the buckets were filled with garden soil. A part of the soil was covered with cement planks to maintain humidity, and soil was sprinkled with water every ten days. Decomposing plant matter, cereals, and occasionally fruits were used as a source of food. From late summer to late fall, laid eggs were collected from soil and counted every three days. Eggs were placed in Petri dishes lined with damp filter papers at a temperature fluctuating between 25 to $30{ }^{\circ} \mathrm{C}$ where hatching time and hatched eggs were daily recorded. To monitor the first mating of beetles and their beginning of oviposition, some of tens of newly emerged adults (male and female) carried out in rearing laboratory were daily observed especially after sunset. Prior to that, the size (length and width) of beetles was measured. As they were small and ivory transparent in color, some newly egg hatched larvae were observed under light microscopy; it is there that the antennal and ligula setae innervation have been investigated.

\section{Results}

Blaps nefrauensis is one of about 17 desert darkling beetles (Blaps genus) occurring in Tunisia. Living in urban zones (Moulares, Tunisia), it is more accessible to study its biological development and mating behavior as it inhabits major domestic gardens where it mates, oviposits and feeds. A field survey combined with the laboratory rearing can probably provide a more clear idea about the life history (egg, larva, prepupa, pupae, and imago $\delta$ and $q$ ) of this coleopteran species (Figures 2, 3a-f).

\subsection{Life cycle}

\subsubsection{Emergence and imago}

In Moulares (urban zone in the west south of Tunisia), B. nefrauensis populations occurred generally in the domestic gardens. Adults appeared in early June. The majority imago emerges from soil burrowing and 


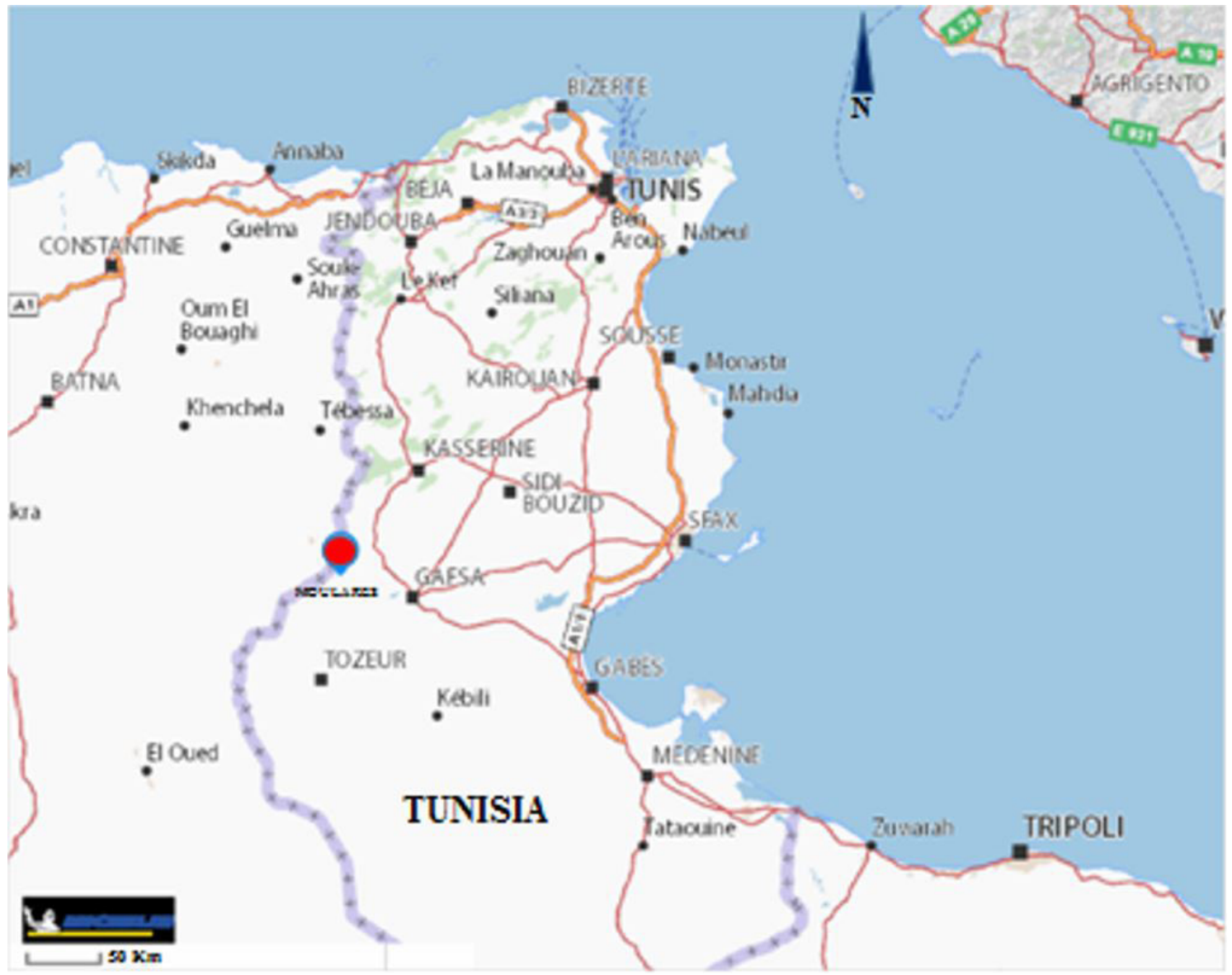

Figure 1. Map of Tunisia (North Africa) showing the localization of the sampling area.

leaving tunnels about $2 \mathrm{~cm}$ in diameter and $30 \mathrm{~cm}$ in depth. Males emerged smaller in size than females (mean values: $4 \mathrm{~cm}$ in length and $1.5 \mathrm{~cm}$ in width vs. $4.5 \mathrm{~cm}$ in length and $1.8 \mathrm{~cm}$ in width for males and females, respectively). In general, males and females were sexually dimorphic: Females are larger in size than males. Males have abdominal intersternite hair tuft and longer caudal extensions (mucron) (Figure $2 \mathrm{a}-\mathrm{b}$ ). Both males and females began to mate about one week after their emergence (June) and continue mating throughout their lifetime. The mating period starts from June to November peaking in August when beetles are most evident. At night (from dusk till dawn), the majority of pairs adopted almost the same sexual behavior. The male approaches the female, mounts, and remains mounted for up to thirty minutes. During this time female extrudes her ovipositor out of her abdomen (Figure $2 \mathrm{c}$ ) to smooth the insertion and facilitate the fixation of male genitalia on the female vagina (Figure 2d) during more than five minutes. Consequently, male completely extrudes spermatophores inside female abdomen during copulation.

\subsubsection{Oviposition and egg hatching}

In the field, females began the oviposition from late July to late November, peaking in September. They lay their eggs in soil covered by decomposition matter, under stones, and under cement and wooden planks. Because of the high temperature and low humidity, embryogenesis can really be accomplished only from mid-August. Laboratory conditions show that females dig in the soil (2-40 mm) and lay eggs scattered (soil moisture and softness may help females dig deep into the soil and lay their eggs). Females lay between 1 to 6 eggs per day during summer and autumn seasons. In the breeding laboratory females stay alive, but give up laying eggs. Eggs were ovoid in form, white in color and approximately $2.7 \mathrm{~mm}$ in length and $1.5 \mathrm{~mm}$ in width. The duration of eggs development till hatching was around 9 days for the majority. New hatching larvae ( $1^{\text {st }}$ instar) were transparent white in color and $4.5 \mathrm{~mm}$ in length (Figure 3a).

\subsubsection{Larvae and pupation}

As well-known, species belonging to order Coleoptera present a complete metamorphosis involving several 


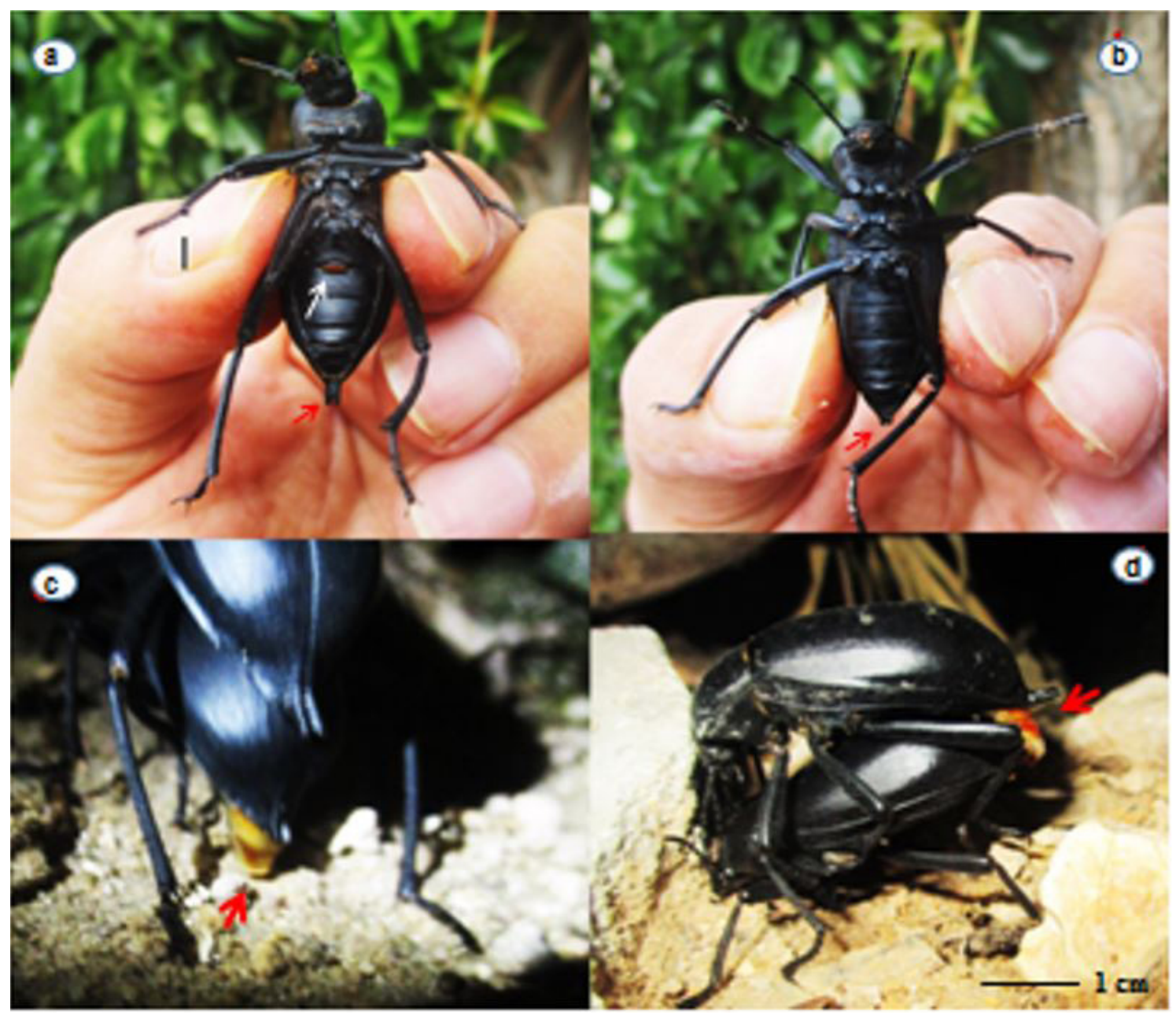

Figure 2. Morphological dimorphism and mating in B. nefrauensis. (a) Male ventral view, (b) Female ventral view, (c) Female ovipositor, (d) Male genitalia.

larval instars. These instars are followed by a nonfeeding pupal stage, which gives rise directly to the adult. An active survey in the laboratory combined with a field examination showed that, in B. nefrauensis populations, the number of instars intervening between the egg and the pupa ranged from 14 to 16 . Figure $3 g-j$ can give an idea about the moulting phenomena in the Blaps larva. As shown in Figure 3a-f, the larval stage began with the newly hatched larva (hereafter, first instar). First larval instar was white in color and very small, a little bit longer than an egg (Figure 3a). Within three days approximately, it changes gradually to yellowish giving the second larval instar (Figure 3b) which is clearly different in size $(7 \mathrm{~mm}$ vs. $4.5 \mathrm{~mm}$ long in mean) and color (shiny yellow). In the field, larvae in different instars were hidden under stones and planks or inside their borrowed tunnels. Larvae began to appear in the garden at the end of August. The majority of $B$. nefrauensis larvae moulted between 14 and 16 times. In every inter-moulting period, larvae become white in color, leaving its old yellow cuticle (they turn yellow in color within two days on average. Figure 3g-j showed some of moulting larvae in different instar stages. In midMay, most of the larvae were in the last instar (Figure 3c) reaching a constant size $(\sim 6 \mathrm{~cm})$. They enlarge the external part of their tunnels and enter in to the prepupal stage (Figure 3d). This was a semi-dormant and non-feeding stage in which the prepupae shortened in size and lost weight. After about four days, they pupate on the enlarged base of the tunnels. At the population level, pupation occurred from middle May to mid-June. Pupa appears to be white in color (Figure 2e) lasting about 12 days in that non-feeding stage. In June, adults (Figure 3f) emerge from the soil, fulfill their biological functions during summer and autumn and die before winter leaving their larvae in the field as a new generation.

\subsubsection{Summary}

Blaps nefrauensis is usually found at night around human waste food, and near plant and stones. In an urban area it has been associated with domestic gardens. Because of its North Africa origin (Soldati et al., 2017), adults were well suited with summer climate (high temperature and 

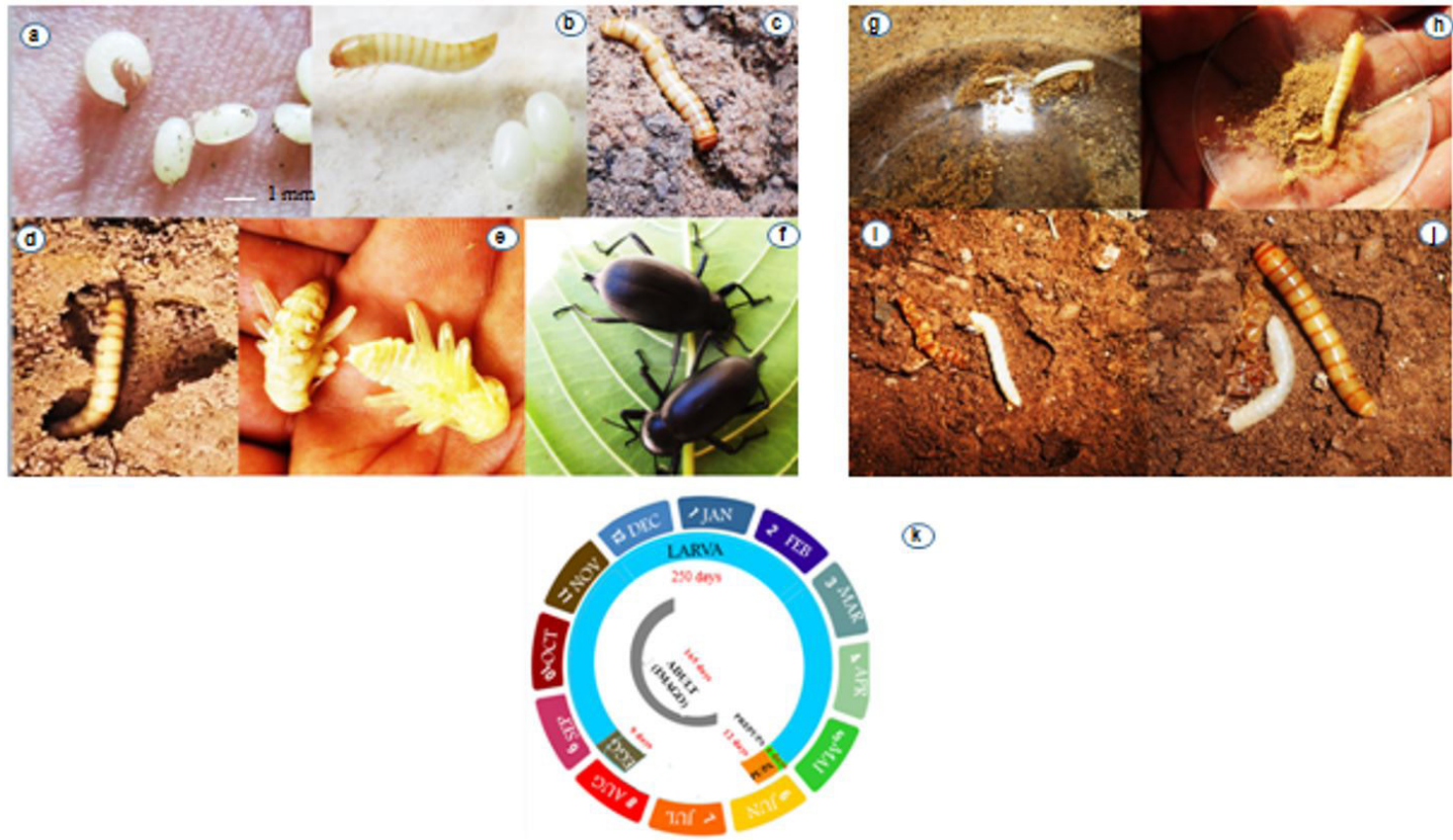

(א)

Figure 3. B. nefrauensis life cycle: (a) Eggs and newly hatched larva (1 $1^{\text {st }}$ instar). (b) $2^{\text {nd }}$ instar larva beside eggs. (c) Larvae in the last instar. (d) Prepupa. (e) Pupa. (f) Adults. (g) Newly moulted $2^{\text {nd }}$ and $4^{\text {th }}$ instar larvae. (h) Moulted $2^{\text {nd }}$ and $6^{\text {th }}$ instar larva began to yellowish. (i) Newly moulted larva beside its old yellow cuticle. (j) Newly moulted larva compared with larva in the $8^{\text {th }}$ instar. Diagram representation of the life cycle of B. nefrauensis (k).

low humidity). They were active during summer and autumn before their expiration in winter. Beetle activity decreases when it's windy and intensifies mostly after the rain if there is no wind. Adults can live six months continuing to feed, mate and produce eggs most of their lives. They feed on decomposing plant matter, fruits, cereals, bread, cooked meat and vegetable, pasta, rest of soup, chickpea etc.) They began to mate about seven days after their emergence. Mating increases normally after rain peaking in August. Female laid their eggs from late July in moist soil, and under stones and planks. Larvae normally hatch in nine days and develop into adults in about 250 days (autumn, winter and spring). Since summer days are characterized by high temperature (more than $35^{\circ} \mathrm{C}$ reaching $45^{\circ} \mathrm{C}$ ) and low humidity, larvae survived only from the beginning of autumn. There are approximately fifteen larval instars. Larvae were usually hidden in soil digging tunnels or under stones. Sometime when the weather is moderate (no wind, no rain, no sirocco), larvae may leave their tunnel and shelters for a night walking on the ground crossing decomposing organic matter. As all beetles belonging to order Coleoptera, $B$. nefrauensis is a holometabolous insect with complete metamorphosis. Figure 3k depicts its life cycle. The field observation revealed that during summer months, eggs and larvae died under high temperature (in the field, second instar larvae can be observed from September). Then, the life cycle began with eggs laid at the beginning of autumn with embryogenesis duration of about 9 days. Newly hatched larva continues its development (fifteen instars) to the pupation stage lasting about 9 months (from September to late May). Then the larva stopped feeding and entered into the prepupa stage for about four days. During the first half of June it submits a metamorphosis transforming into the pupal stage which lasts twenty days on average. In mid-June the adult emerges and remains alive until late autumn fulfilling its biological function. In winter adults expire leaving their larvae in the soil as a new generation. Approximately, the duration of every stage: eggs, larvae, prapupae, pupa and adults were $9,250,4,12$, and 165 days, respectively (about 14.5 months total). In the breeding laboratory, adults males and females in captivity reached their second year and still alive and active. Females laid eggs for the second season.

\subsection{Notes on the first instar larvae}

Newly hatched eggs larvae were small in size and white in color, yet when seen under light microscope, they appear to be rather transparent. This has allowed visualizing the external morphology with more details and occasionally observing nerve fibers through the cuticle in some areas. Herein, the external morphology will be described briefly. The innervation of the antennal and the ligular setae are the main object of this contribution.

Body of the first instar larvae (Figure 4a) elongate and subcylindrical, length $4.5-5 \mathrm{~mm}$, color ivory-white with dark red mandibles, integument soft, thoracic and abdominal segments subcylindrical ninth abdominal segment triangular with two small urogomphi and two 

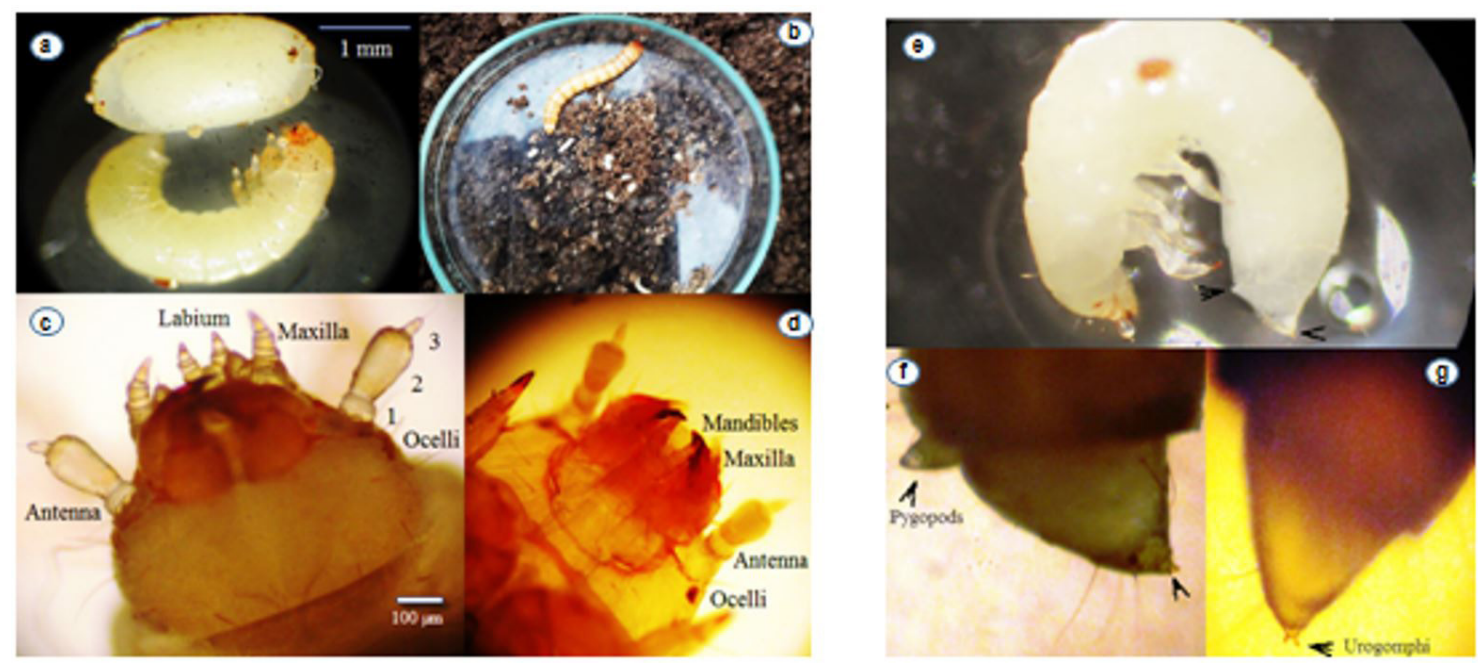

Figure 4. Newly egg hatched larva: (a) First instar larva compared with egg, scale $=1 \mathrm{~mm}$. (b) First instar larva compared with $8^{\text {th }}$ instar larva. (c) Head (dorsal view). (d) Head (ventral view). (e-g) Pygopods and urogomphi in first instar larva

pygopods subconical well visible (Figure 4e-g) Compared with older instar, newly egg hatched larvae are very small (Figure 4b).

Head (Figure 4c, d) Prognathous, wider than long, convex above, lateral margins rounded lateral side behind antenna bears brown ocelli. Ocelli arranged in an anterior group of three and a posterior group of two on each side. Antenna three-segmented, antennomere 1 cylindrical as wide as long, antennomere 2 widest distally (pear or spinning top-shaped), three time longer than wide and about 3.5 times than the first (longer than the other two segments together), bearing apically small sensilla surrounding the base of segment 3 , antennomere 3 short and cylindrical, about $1 / 5$ diameter and long of second, apically bearing a long erect seta surrounded with a diversity of small sensilla. Maxillary palpi (Figure 5c) distinctly three-segmented with sensory area on apex and single seta in each segment, lacinia (Figure 5b) with some of ten teeth, galea with a tuft of setae at apex surrounded by small sensilla. Labial palpi (Figure $5 \mathrm{c}$ ), two-segmented (appear to be three-segmented in dorsal view having the same shape of maxillary palpi). Ligula with two long erect setae on tip, visible in ventral view and occasionally in dorsal view (Figure 5a,c). Mandibles well developed with two apical teeth. The dorsal view showed that paired mandibles composed of two lobes superimposed and inserted well in the clypeus (Figure 4c).

Further investigation using light microscopy and zoom of the camera (Canon IXUS) showed that the two ligular setae appear to be innervated with two nerve fibers across the ligula (Figure 5e). Similarly, the apical antennal seta seems to be innerved with single nerve fiber across the third antennal segment (Figure 5f).

Note, an examination on the larvae (embryo) just before egg hatching showed furthermore that the antennae are covered by a fine cylindrical film protecting apically the antennal sensilla (Figure 5g, h).

\section{Discussion}

\subsection{Life cycle and biology}

Tunisia is located in the central part of North Africa. The Country belongs to the Mediterranean region, which is well known for its high biodiversity. It is also a part of the Maghreb area which is an important Pleistocene glacial refuge both in North Africa and in the Western Palearctic (Myers et al., 2000; Husemann et al., 2013). The first data on Tunisian beetles come from the $19^{\text {th }}$ and starting of the $20^{\text {th }}$ centuries (Vigors 1825; Fairmaire 1858; Seidlitz 1893; Bedel 1895, 1900; Bodemeyer, 1927; Normand, 1933; Mandl, 1935). Among about 250 species belonging to the Blaps genus distributed worldwide, about 17 Blaps species was recorded in Tunisia (including B. nitiduloides Soldati, 2017 and B. teocchii Soldati, 2017 were recently identified). Of these, B. nefrauensis nefrauensis Seidlitz, 1893, was recorded in the Tunisian desert between Gabes and Gafsa (Soldati et al., 2017). Moulares is a town and commune in the Gafsa Governorate, Tunisia. It is part of the west-central arid region of Tunisia and has a dry climate marked by Mediterranean and continental influences. The city is located in a transition zone between the steppe and desert (Karaouli et al., 2009; Mohamed et al., 2013; Raja et al., 2014). It seems that our study beetle preferred Moulares, inhabiting the domestic gardens where they have easy access to food and shelter (humidity, decomposing matters, concealed shelters...). Its complete life cycle with egg, larva, pupa, and adult was in summary about 15 months. Every year in the same month (June) the adults emerged. Furthermore, in the same period (mid-May) larvae began to pupate. Here again, every year before winter adults expired (the same phenomena is repeated every year). Therefore, we assumed that the duration of every generation is one year. Beetles belonging to the Blaps genus vary significantly in their biological development duration. 

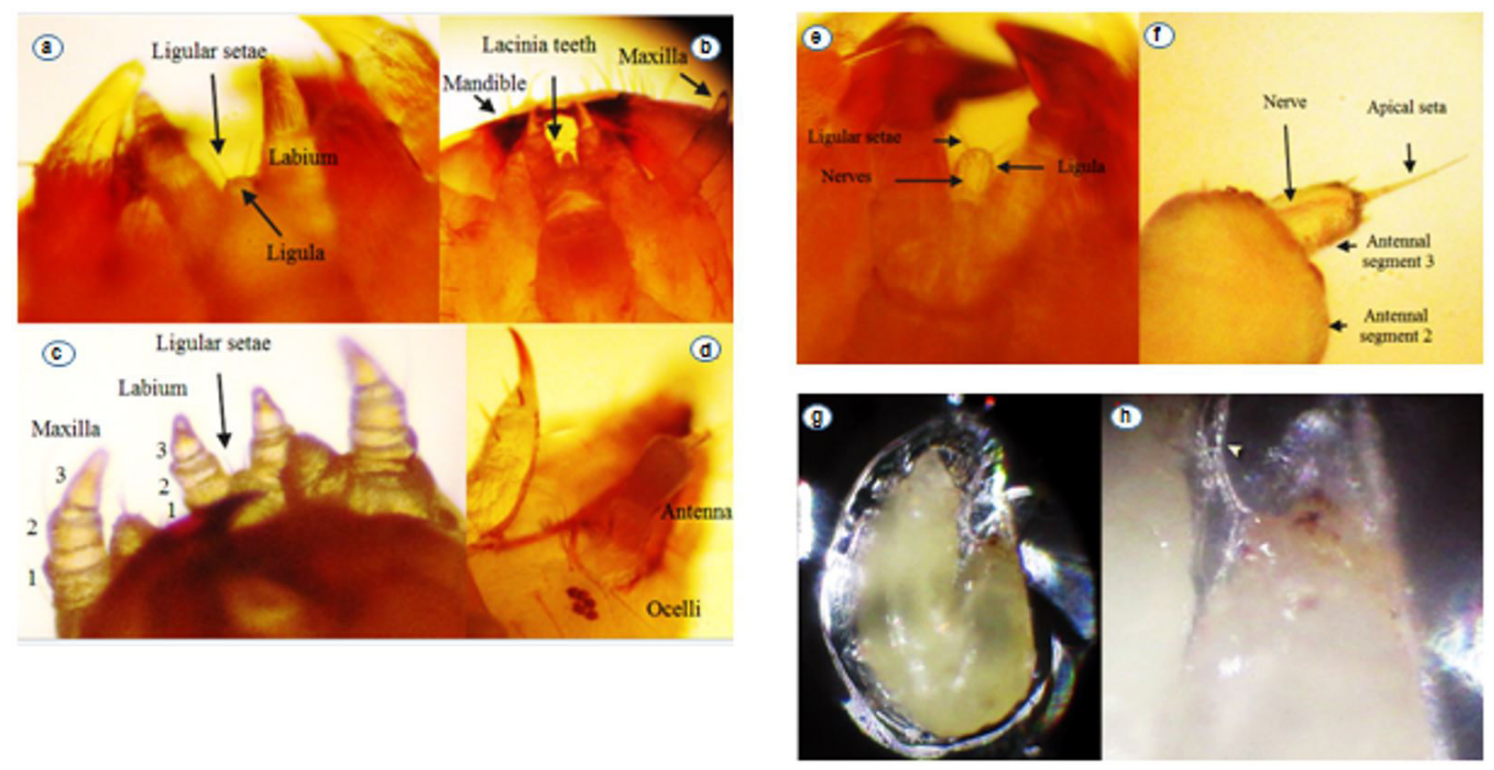

Figure 5. Light microscopy of some structure of the newly hatched egg larva of B. nefrauensis: (a) Ligula (ventral view). (b) Lacinia teeth (ventral view). (c) Ligula, and Labial and Maxillary palpi (dorsal view). (d) Ocelli (lateral view). (e) Nerves across ligula. (f) Nerve across third antennomere. Light microscopy on the antennal protection in the embryo of B. nefrauensis ( $\mathrm{g}$ ) Larva just before egg hatching. (h) Cylindrical membrane covering apically the antennae.

According to Knor (1975), B. lusitanica populations have a three-year life cycle. However, the development period of B. kollari doesn't reach one year (Menon and Putnam, 1988). In laboratory conditions, larval development of $B$. Kollari was reported as being very rapid, lasting only 80 days or less. Authors attributed the rapid development to an adaptation in Blaptinii living in arid conditions to make the best use ephemeral moisture. De Los Santos et al. (2006) exanimated the correlation between thermal habitats and the life cycle of two species belonging to the Pimelia genus (Tenebrionidae) on two extreme sites along an elevation ranges on Tenerif (Canary Islands). They concluded that $P$. ascendens presented a two years life cycle with larvae and adults overwintering. However $P$. canariensis had one year life cycle. This difference was explained that in addition to the two species inhabiting different ecological systems, they also need to synchronize their life history with climatic fluctuations of different intensities. Multiyear life cycles are common in order Coleoptera. Larval development of some species of the Scarabaeidae family takes up to two years reaching 5 years in different climatic zones. In Lucanidae, Carambycidae, Alleculidae and many other Coleopteran families, the biological development of various species can reach 5 years or more (Saulich, 2010). Short life cycles are also somewhat prevalent in beetles (Danks, 2006). Concerning our study beetle $B$. nefrauensis, the annual variation in temperature plays the principal role in its biological development. Thus, adults expire under the low temperature in winter while larva stage can't exceed late spring due to high temperature. In the beginning of summer larvae pupate or expire under the high temperature and low humidity.
However, larvae of certain darkling beetles as tribe Helopini (Tenebrionidae) in the arid zone of European Russia can migrate deep into the soil and have a summer diapause (Byzova and Ghilarov, 1956).

In the gardens, the soil was frequently watered and the humidity appears to be kept up during all seasons in soil. Consequently, the majority of laid eggs hatched and the majority of larvae in the first instar attain pupation. Adults found in gardens were able to oviposit, feed and find shelter. Therefore, we assume that the availability of moisture and food in the urban area increase the frequency of our study insect. Hence, B. nefrauensis populations inhabited urban zones and occupied gardens as an adaptive strategy to survive and to increase their abundance keeping their life cycle duration around one year under the arid and desert climate. In rearing conditions, males and females collected two years ago are still alive and active. This is maybe not strange because other species of the genus Blaps from Tunisia like B. nitens requini lived in the laboratory for about six years (CloudsleyThompson, 1956). Our finding suggests that imago expire in the early years in the fields under various factors (cold, wind, snow, and rain) which tend to intensify in wintertime. All of these factors together, in addition to starvation can begin to disrupt the species' refuges and habitats to the point that they reach levels that would be lethal to adult Blaps during the cold season. It is believed that if adults spend only the winter in rearing and the remaining seasons in the field, they can remain alive and active for many years.

\subsection{Innervation in ligula and antennae}

In insects, the chemical senses are important to detect various types of environmental chemical information. 
The gustatory and olfactory receptors play an important role in feeding and reproduction, where sensory neurons for the perception are found (Hallem et al., 2006; Shields, 1994). The gustatory receptor neurons are present mostly in the mouthparts; whereas the olfactory receptors neurons are located on the antennae (Van der Goes van Naters and Carlson, 2006). Crouau (1997) mentioned that mechanosensitive neurons associated with insect setae are bipolar cells with an axon and a dendrite, and linked further to the physical environment. Coleopteran larvae are provided in a family of sensory structures known as sensilla, present on the antennae, mouthparts, wing, legs and the ovipositors (Crouau, 1997). The larval antenna is an important sensory organ thanks to a variety of associated sensilla that perform various functions: mechanoreception, vibroreception, proprioreception, and thermo-hygroreception. In Elateridae, Faucheux (2014) listed sex groups of sensilla (aporous sensilla chaetica, uniporous sensilla chaetica, long aporous sensillum chaeticum, sensillum campaniformium, sensillum styloconicum, and sensilla basiconica) distributed over the antennal three-segments in Drilus mauritanicus larvae. He mentioned that the number of long setae (chaetica) in the larvae of $D$. mauritanicus (Elateridae) is 16 as against only one in the antennal larvae of the tenebrionid Tribolium ssp. This difference in the number of long sensilla can be explained the different lifestyle in the two larvae. Thus, the variety and the high number of sensilla chaetica can be useful as gustative and mechanoreceptors for the predator larvae of Drillus.

The larval palps are covered by different categories of sensilla which have various receptions. Corbière-Tichané (1969) has classified the sensory tuft crowning the extremity of palps in Speophyes lucidulus larvae (Coleoptera, Catopidae) into eight different groups. The main types of sensory organs were present: mechanoreceptors, olfactory, and gustatory receptors. He has also described a sensillum with a particular structure. The author especially described eight pairs of sensilla located on the ventral surface of the ligula, number of them were campaniformia and basiconica sensilla. He affirmed that all the receptors of the ligula have a simple innervation (dendritic) and may present various types of mechanoreceptors.

In tenebrionidae, the last instar larvae of Tribolium ssp and Tenebrio molitor have three-segmented antennae. The reduced terminal segment bears apically a single long seta, the trichoid terminal sensillum surrounded by several types of small sensilla. Behan and Ryan (1978) cited five categories of sensilla (trichoid, styloconic, placoid, campaniform, and coeloconic sensilla) as antennal receptors in Tribolium larvae. The trichoid sensillum is a long, thin and aporous seta innervated by one or two bipolar neurons (Bloom et al., 1982; Behan and Ryan 1978). It can be considered as a sensillum filiformium sensitive to air currents (vibroreceptor or anemoreceptor), possess also probably gustative or chemoreceptive functions (Faucheux, 2014).

Our results supported by findings of Behan and Ryan (1978) for the genus Tribolium and Bloom et al. (1982) for Tenebrio molitor, were shown that the third antennal segment in $B$. nefrauensis larvae bears different types of sensilla with single long seta crowning apically the tip. Under light microscopy, the apical seta appears to be linked with single nerve fiber cross the terminal segment. Hence, the structure agrees with larvae of these cited species placed on Tenebrionidae in number, form and associated innervation of the antennal sensory organ.

An examination of the ligula in the newly egg hatched larvae revealed the presence of two nerve fibers innervating two apical setae; it is there that each seta was associated with one fiber crossing the ligula. It is important here to notice that this structure was shown for the first time under light microscopy. As these two elongate setae can be filiform sensilla, and if we consider that they located centrally in the middle of the larva mouthparts and innervated by paired nerves extend from the tip of the ligula to the nervous system (brain), they give the impression of having gustatory and taste functions sensitive mainly to the organic matter. The structure suggests that ligula is notably involved in the chemodetection of food sources.

Results in our study found also that the antennae in the embryo just before egg hatching were protected apically by a fine cylindrical membrane. This can be explained by the need for the protection of the antennal sentilla (especially the apical seta) during the embryonic stage and the fact that the embryo must stay further from all antennal detections to keep its physiological hemostasis.

\section{Conclusion}

Blaps nefrauensis nefrauensis is a desert beetle found in Tunisia. Populations of this species colonise urban areas in search of a better environment to live and reproduce. The results of our study showed that the lifespans of larval, prepupal,and pupal stages are almost identical to those found in fields or rearing. Conversely, the lifespan of an adult beetle is particularly dependent on the biogeographical conditions and environment of the area and may be extended if living conditions change. Home gardens in good condition provide numerous services to maintain the insect's life cycle. however, Moulares like other cities shows continued and hurried building expansion and management by limiting the garden areas and old structures. So, the removal of soil and construction of new buildings could be fatal to both the imago and its larvae. Moreover, Moulares is a town that belongs to the Gafsa mining area and is known for its phosphate production. Therefore, the beetles inhabiting this industrial area could be affected by the harmful effects of toxic emissions (gas and dust) related to industrialization, but this requires further studies.

\section{Acknowledgements}

We are indebted to Dr. Wafaa Osman (Zoology Department, Faculty of Science, Alexandria University, Egypt) for assistance in identification of the species studied and providing references and notes. In the completion of 
this work we would like to express our appreciation and thanks to Debbie Jennings (CSIRO, Australian National Insect Collection, Canberra, Australia) and Hayet Raddadi (English teacher at the University of Gafsa, Tunisia) for their patience in reviewing the text. The authors extend their appreciation to the deanship of scientific research for funding this article by Taif University Research Supporting Project number (TURSP-2020/225), Taif University, Taif, Saudi Arabia.

\section{References}

BEDEL, L., 1895. Catalogue Raisonné des Coléoptères du Nord de l'Afrique (Maroc, Algérie, Tunisie et Tripolitaine) avec notes sur la faune des îles Canaries et de Madère. Paris: Société Entomologique de France, pp. 1-13.

BEDEL, L., 1900. Exploration scientifique de la Tunisie. Catalogue raisonné des Coléoptères de Tunisie, Première partie. Cicindelidae - Staphylinidae. Exploration Scientifique de la Tunisie, ZoologieColéoptères. Paris, France: Imprimerie Nationale.

BEHAN, M. and RYAN, M.F., 1978. Ultrastructure of antennal sensory receptors of Tribolium larvae (Coleoptera : tenebrionidae). International Journal of Insect Morphology \& Embryology, vol. 7, no. 3, pp. 221-236. http://dx.doi.org/10.1016/00207322(78)90005-3.

BLOOM, J.W., ZACHARUK, R.Y. and HOLODNIUK, A.E., 1982. Ultrastructure of the larval antenna of Tenebrio molitor L. (Coleoptera: Tenebrionidae): structure of the trichoid and uniporous peg sensilla. Canadian Journal of Zoology, vol. 60, no. 7, pp. 1528-1544. http://dx.doi.org/10.1139/z82-202.

BODEMEYER, B.V., 1927. Übermeine Entomologische Reisen. Tunis, Oasis Gafsa und die Khroumerie. Stuttgart, Germany: Alfred Kernen.

BOUCHARD, P., LAWENCE, J.F., DAVIES, A.E. and NEWTON, A.F., 2005. Synoptic classification of the woed Tenebrionidae (Insecta: Coleoptera) with a review of family-group names. Annales Zoologici, vol. 55, pp. 499-530.

BYZOVA, Y.B. and GHILAROV, M.S., 1956. Soil dwelling larvae of Helopini tribe (Coleoptera, Tenebrionidae). Зоологический журнал, vol. 35, no. 10, pp. 1493-1509.

CLOUDSLEY-THOMPSON, J.L., 1956. Studies in diurnal rhythms.: VI. Bioclimatic observations in Tunisia and their significance in relation to the physiology of the fauna, especially woodlice, centipedes, scorpions and beetles. Annals E Magazine of Natural History, vol. 9, no. 101, pp. 305-329. http://dx.doi. org/10.1080/00222935608655817.

CONDAMINE, F., SOLDATI, L., RASPLUS, J.Y. and KERGOAT, G.J., 2011. New insights on systematics and phylogenetics of Mediterranean Blaps species (Coleoptera: Tenebrionidae: Blaptini), assessed through morphology and dense taxon sampling. Systematic Entomology, vol. 36, no. 2, pp. 340-361. http://dx.doi.org/10.1111/j.1365-3113.2010.00567.x.

CONDAMINE, F.L., SOLDATI, L., CLAMENS, A.L., RASPLUS, J.Y. and KERGOAT, G.J., 2013. Diversification patterns and processes of wingless endemic insects in the Mediterranean Basin: historical biogeography of the genus Blaps (Coleoptera: Tenebrionidae). Journal of Biogeography, vol. 40, no. 10, pp. 1899-1913. http:// dx.doi.org/10.1111/jbi.12144.

CORBIÈRE-TICHANÉ, G., 1969. Ultrastructure du labium de la larve du Speophyes lucidulus delarouzeei (Coleoptera, Catopidae). Zeitschrift für Morphologie der Tiere, vol. 66, no. 1, pp. 73-86. http://dx.doi.org/10.1007/BF00298714.
CROUAU, Y., 1997. Comparison of crustacean and insect mechanoreceptive setae. International Journal of Insect Morphology E'Embryology, vol. 26, no. 3-4, pp. 181-190. http:// dx.doi.org/10.1016/S0020-7322(97)00020-2.

DANKS, H.V., 2006. Short life cycles in insects and mites. Canadian Entomologist, vol. 138, no. 04, pp. 407-463. http://dx.doi. org/10.4039/n06-803.

DE LOS SANTOS, A., FERRER, F., DE NICOLAS, J.P. and CRIST, T.O., 2006. Thermal habitat and life history of two congeneric species of darkling beetles (Coleoptera: Tenebrionidae) on Tenerife (Canary Islands). Journal of Arid Environments, vol. 65, no. 3, pp. 363-385. http://dx.doi.org/10.1016/j.jaridenv.2005.08.001.

DE LOS SANTOS, A., MONTES, C. and DIAZ, L.R., 1988. Life histories of some darkling beetles (Coleoptera: Tenebrionidae) in two Mediterranean Ecosystems the Lower Gyutalquivir (Southwest Spain). Environmental Entomology, vol. 17, no. 5, pp. 799-814. http://dx.doi.org/10.1093/ee/17.5.799.

FAIRMAIRE, L., 1858. Essai sur les Coléoptères de Barbarie. Annales de la Société Entomologique de France, vol. 3, no. 6, pp. 743-747.

FAUCHEUX, M.J., 2014. Antennal sensilla of the primary larva of the false firefly beetle Drilus mauritanicus Lucas, 1849 (Coleoptera, Elateridae, Agrypninae, Drilini). Bulletin de l'Institut Scientifique: Section Sciences de la Vie, Vol. 36, pp. 57-64.

HALLEM, E.A., DAHANUKAR, A. and CARLSON, J.R., 2006. Insect odor and taste receptors. Annual Review of Entomology, vol. 51, no. 1, pp. 113-135. http://dx.doi.org/10.1146/annurev. ento.51.051705.113646. PMid:16332206.

HALSTEAD, D.G.H., 1967. Biological studies on species of Palorus and Coelopalorus with comparative notes on Tribolium and Latheticus (Coleoptera: tenebrionidae). Journal of Stored Products Research, vol. 2, no. 4, pp. 273-313. http://dx.doi. org/10.1016/0022-474X(67)90076-8.

HUSEMANN, M., SCHMITT, T., ZACHOS, F.E., ULRICH, W. and HABEL, J.C., 2013. Palaearctic biogeography revisited: evidence for the existence of a North African refugium for Western Palaearctic biota. Journal of Biogeography, vol. 41, no. 1, pp. 81-94. http:// dx.doi.org/10.1111/jbi.12180.

KARAOULI, F., TOUZI, S., TARHOUNI, J. and BOUSSELMI, L., 2009. Improvement potential of the integrated water resources management in the mining basin of Gafsa. Desalination, vol. 246, no. 1-3, pp. 478-484. http://dx.doi.org/10.1016/j. desal.2008.03.069.

KNOR, I.B., 1975. Life cycles of darkling beetles (Col: Tenebrionidae) of Tuva. The Soviet Journal of Ecology, vol. 6, pp. 458-461.

LÖBL, I., NABOZHENKO, M.V. and MERKL, O., 2008. Tribe Blaptini Leach, 1815. In: I. LÖBL \& A. SMETANA (Eds.), Catalogue of Palaearctic Coleoptera. Stenstrup: Apollo books, Vol. 5, pp. 219-257.

MANDL, K., 1935. Cicindela litorea Forsk., C. Lyoni Vigors und ihre Rassen (4. Beitrag zur Kenntnis paläark $\neg$ tische Cicindelen). Koleopterologische Rundschau, vol. 21, no. 5, pp. 178-182.

MATTHEWS, E.G., LAWRENCE, J.F., BOUCHARD, P., STEINER, W.E. and ŚLIPINSKI, S.A., 2010. Chapter 11.14. Tenebrionidae Latreille, 1802. In R.A.B. LESCHEN, R.G. BEUTEL and J.F. LAWRENCE, eds. Handbook of zoology. A natural history of the phyla of the animal Kingdom. Berlin: Walter de Gruyter, vol. IV - Arthropoda: Insecta. Part 38. Coleoptera, Beetles, Vol. 2: Systematics (Part 2), pp. 574-659.

MENON, M. and PUTNAM, S.J., 1988. Some Aspects of the Developmental Biology of Blaps kollari (Coleoptera: Tenebrionidae) Under Laboratory Conditions. Annals of the Entomological Society of America, vol. 81, no. 5, pp. 836-843. http://dx.doi.org/10.1093/aesa/81.5.836. 
MOHAMED, R.T., TAIEB, D. and BEN IBRAHIM, A., 2013. Evaluation of Nitrogen Oxides pollution in industrial area, Mdhilla (mining basin of Gafsa, south western of Tunisia) with aid of GIS. Industrial Journal of Scientific Research and Engineering Technology (IJSET), Vol. 2, pp. 1-24.

MYERS, N., MITTERMEIER, R.A., MITTERMEIER, C.G., DA FONSECA, G.A.B. and KENT, J., 2000. Biodiversity hotspots for conservation priorities. Nature, vol. 403, no. 6772, pp. 853-858. http://dx.doi. org/10.1038/35002501. PMid:10706275.

NORMAND, H., 1933. Contribution au Catalogue des Coléoptères de la Tunisie. Premier supplément. Bulletin de la Société d'Histoire Naturelle d'Afrique du Nord, vol. 29, pp. 149-151.

NORMAND, H., 1937. Contribution au Catalogue des Coléoptères de la Tunisie. Bulletin de la Société d'Histoire Naturelle de l'Afrique du Nord, vol. 28, no. 4, pp. 232-269.

RAJA, M., DALILA, T. and AMMAR, B.B., 2014. Chemical and Mineralogy Characteristics of Dust Collected Near the Phosphate Mining Basin of Gafsa (South-Western of Tunisia). Journal of Environmental \& Analytical Toxicology, vol. 04, no. 06. http:// dx.doi.org/10.4172/2161-0525.1000234.

SAULICH, A.K., 2010. Long life cycles in insects. Entomological Review, vol. 90, no. 9, pp. 1127-1152. http://dx.doi.org/10.1134/ S0013873810090010.

SEIDLITZ, G.V., 1893. Naturgeschichte der indekten Deutschlands erste abteilung Coleoptera. Berlin: R. Stricker. 1896 Edition. Nicolaische Verlags-Buchhandlung.

SHIELDS, V.D.C., 1994. Ultrastructure of the uniporous sensilla on the galea of larval Mamestra configurata (Walker) (Lepidoptera: noctuidae). Canadian Journal of Zoology, vol. 72, no. 11, pp. 2016-2031. http://dx.doi.org/10.1139/z94-273.
ŚLIPINSKI, S.A., LESCHEN, R.A.B. and LAWRENCE, J.F., 2011. Order Coleoptera Linnaeus, 1758. In: Z.-Q. ZHANG, ed. Animal biodiversity: an outline of higher-level classification and survey of taxonomic richness. Zootaxa, Vol. 3148, pp. 203-208.

SOLDATI, L., CONDAMINE, F.L., CLAMENS, A.L. and KERGOAT, G., 2017. Documenting tenebrionid diversity: progress on Blaps Fabricius (Coleoptera, Tenebrionidae, Tenebrioninae, Blaptini) systematics, with the description of five new species. European Journal of Taxonomy, vol. 282, no. 282, pp. 1-29. http://dx.doi. org/10.5852/ejt.2017.282.

SOLDATI, L., KERGOAT, G.J. and CONDAMINE, F.L., 2009. Important notes on taxonomic structure of Blaps nitens Laporte de Castelnau, 1840 with the description of new subspecies Blaps nitens medvedevi subsp. n. (Coleoptera: Tenebrionidae: Blaptini). Caucasian Entomological Bulletin, vol. 5, no. 2, pp. 231-234. http://dx.doi.org/10.23885/18143326-2009-5-2-231-233.

VAN DER GOES VAN NATERS, W. and CARLSON, J.R., 2006. Insects as chemosensors of humans and crops. Nature, vol. 444, no. 7117, pp. 302-307. http://dx.doi.org/10.1038/nature05403. PMid: 17108954.

VIGORS, M., 1825. On some subjects of zoology. Zoological Journal, vol. 1, pp. 413-415.

ZANUNCIO, J.C., MOLINA-RUGAMA, A.J., SERRAO, J. and PRATISSOLI, D., 2001. Nymphal Development and Reproduction of Podisus nigrispinus (Heteroptera: Pentatomidae) Fed With Combinations of Tenebrio molitor (Coleoptera: Tenebrionidae) Pupae and Musca domestica (Diptera: Muscidae) Larvae. Biocontrol Science and Technology, vol. 11, no. 3, pp.331-337. http://dx.doi. org/10.1080/09583150120055736. 